\title{
THE SEPARATION OF POWERS IN THE WTO: HOW TO AVOID JUDICIAL ACTIVISM
}

\author{
LORAND BARTELS*
}

\section{INTRODUCTION}

As with other legal systems based on a separation of powers, the World Trade Organization is marked by a degree of tension between its political organs and its quasi-judicial organs, in particular the Appellate Body. In late 2000 this tension spilled out into the public domain, when the Appellate Body announced a procedure for the filing of amicus curiae briefs in the EC-Asbestos case. ${ }^{1}$ The question of public participation in WTO dispute settlement proceedings is sensitive to many WTO Members, and in expressly encouraging the submission of amicus briefs in this way the Appellate Body was felt to be overstepping its functions. ${ }^{2}$ In the end, this dispute settled with a draw, the Appellate Body deciding that it had no need to consider any of the amicus briefs submitted in that particular case, and yet still maintaining that panels and the Appellate Body have the right to take unsolicited amicus briefs into account, should they so choose.

In retrospect, the amicus dispute marked a watershed in the history of the WTO. Prior to this dispute, despite occasional misgivings as to the results of individual cases, the WTO dispute settlement system (meaning primarily the Appellate Body) was reverentially referred to as the 'jewel in the crown' of the WTO. Since then, it has become fair game for those frustrated with what they perceive as 'judicial activism'. Probably the best known of the Appellate Body's critics is Claude Barfield, who, collecting grievances from across the political spectrum, has called for a sharp reduction in the powers of panels

\footnotetext{
* Lecturer in International Economic Law, University of Edinburgh. A draft of this paper was presented at the Symposium on Dispute Settlement Reform, College of Europe, 5-6 Dec 2003. am very grateful to the participants at this Symposium for their reactions. I have also been privileged to receive comments from Dapo Akande, Alan Boyle, Steve Charnovitz, Ignacio Garcia Bercero, Bill Davey, Piet Eeckhout, Lothar Ehring, Paolo Garzotti, Rob Howse, Petros Mavroidis, Edmond McGovern, Federico Ortino, Philip Pierros, and Soren Schonberg. All errors are my own.

1 WTO Appellate Body Report European Communities-Measures Affecting Asbestos and Asbestos-Containing Products ('EC-Asbestos'), WT/DS135/AB/R, adopted 5 Apr 2001.

2 The outcry is recorded in General Council Minutes of Meeting held on 22 November 2000, WT/GC/M/60, 23 Jan 2001. There is a substantial literature on the amicus dispute. See, eg, GA Zonnekeyn 'The Appellate Body's Communication on Amicus Curiae Briefs in the Asbestos Case-An Echternach Procession?' (2001) 35 Journal of World Trade 553 and G Marceau and M Stilwell 'Practical Suggestions for Amicus Curiae Briefs Before WTO Adjudicating Bodies' (2001) 4 Journal of International Economic Law 155.
}

[ICLQ vol 53, October 2004 pp 861-895] 
and the Appellate Body and a return to the more diplomatic methods of dispute settlement current under the old GATT system. ${ }^{3}$ This may be extreme, but other proposals are not far behind. ${ }^{4}$

It is against this background that this article seeks to make a contribution. Though it takes the position that panels and the Appellate Body have not so far exceeded their authority to determine disputes arising under the various WTO agreements, it accepts that there could be situations in which these organs may trespass onto ground better occupied by the WTO political organs. Indeed, it suggests that in some cases this may be unavoidable. And this is because, unlike most 'ordinary' courts and tribunals, panels and the Appellate Body are extremely limited in their ability to manage cases that are inappropriate for resolution in dispute settlement proceedings. They have no power to declare cases 'inadmissible', they are unable to suspend proceedings while a relevant decision is taken in another forum, and they are unable to declare that the law which they are bound to apply is incapable of determination. The suggestion made in this article is therefore that the solution to potential judicial activism is not further to weaken the powers of panels and the Appellate Body, but rather, in these specific circumstances, to make them stronger.

The article proceeds as follows. Section II describes the powers of the political and quasi-judicial organs under the WTO Agreement, and explains why the intended relationship between these two sets of powers does not work in practice. ${ }^{5}$ Section III outlines some of the institutional reforms that have been proposed to date. Section IV asks whether there are some types of disputes that are inherently unsuitable for dispute settlement proceedings, focusing on disputes with a politically sensitive subject matter, disputes where the law is indeterminate, and disputes involving questions of 'institutional balance'. This section also suggests various ways in which the tensions caused by these types of disputes might be reduced by strengthening the powers of the panels and the Appellate Body. Section V concludes.

\section{THE SEPARATION OF POWERS UNDER THE WTO AGREEMENT}

That there should be difficulties within the WTO with an allegedly 'activist' court is not immediately apparent from a reading of the WTO Agreement,

\footnotetext{
3 CE Barfield Free Trade, Sovereignty, Democracy: The Future of the World Trade Organization (Washington DC AEI Press 2001).

${ }^{4}$ For a review of the issues, see S Charnovitz 'Judicial Independence in the World Trade Organization' in Boisson de Chazournes, Romano and Mackenzie (eds) International Organizations and International Dispute Settlement: Trends and Prospects (Ardsley NY Transational Publications 2002) and, for a political science perspective, J McCall Smith 'WTO Dispute Settlement: The Politics of Procedure in Appellate Body Rulings' (2003) 2 World Trade Review 65.

5 All the WTO agreements and other instruments are available at <http://www.wto.org>.
} 
which gives pride of place to the WTO political organs. At the apex is the Ministerial Conference, which meets at least every 2 years, and has the power to take decisions on all matters under any of the multilateral WTO agreements. ${ }^{6}$ On a day-to-day basis, the full authority of the Ministerial Conference is exercised by the General Council, which is assisted by numerous Councils, Committees, and other subordinate bodies established to administer the many other agreements constituting the WTO legal system. ${ }^{7}$ In principle, voting on ordinary matters is relatively liberal. While Article IX:1 of the WTO Agreement states that '[t]he WTO shall continue the practice of decision-making by consensus followed under GATT 1947', it continues by allowing that 'except as otherwise provided, where a decision cannot be arrived at by consensus, the matter at issue shall be decided by [majority] voting'. Footnote 1 to the WTO Agreement explains that '[t]he body concerned shall be deemed to have decided by consensus on a matter submitted for its consideration, if no Member, present at the meeting when the decision is taken, formally objects to the proposed decision. ${ }^{\prime 8}$

The General Council also convenes as the Dispute Settlement Body (DSB) when exercising its functions under the Dispute Settlement Understanding (DSU). In this capacity, it operates with its own Chairman and under its own rules of procedure. ${ }^{9}$ The DSB takes decisions by consensus, ${ }^{10}$ including decisions not to establish a panel and not to adopt panel or Appellate Body reports. ${ }^{11}$ The primary responsibilities of the DSB are 'to establish panels, adopt panel and Appellate Body reports, maintain surveillance of implementation of rulings and recommendations, and authorize suspension of concessions and other obligations under the covered agreements'. ${ }^{12}$ The role of

6 Art IV:1 of the WTO Agreement. The Agreement on Government Procurement and the Agreement on Trade in Civil Aircraft, set out in Annex 4 to the WTO Agreement, are plurilateral rather than multilateral, and are subject to different rules (see Art IV:8 of the WTO Agreement). The two other plurilateral agreements in Annex 4 are defunct.

7 See PJ Kuijper 'Some Institutional Issues Presently Before the WTO' in Kennedy and Southwick (eds) The Political Economy of International Trade Law: Essays in Honor of Robert E. Hudec (Cambridge CUP 2002). This Article observes that some of the decisions made by the Ministerial Conference do not make it clear that this (and a fortiori the other bodies) is an organ of the WTO, not an ad hoc conference of ministers (at 107).

8 The Councils, Committees and other subordinate bodies of the WTO are mandated by Rule 33 of their respective Rules of Procedure to refer a matter to the General Council whenever they are unable to reach a decision by consensus. For an example, see WTO Document Rules of Procedure for Meetings of the Council for Trade in Goods, WT/L/79, 7 Aug 1995. For a discussion of Rule 33, see Kuijper, above n 7 at 103-6. The authority to adopt Rules of Procedure is found in paras 5-7 of Art IV of the WTO Agreement.

9 Art IV:3 of the WTO Agreement.

10 Art 2.4 DSU. Echoing footnote 1 of the WTO Agreement, footnote 1 of the DSU states that ' $[\mathrm{t}]$ he DSB shall be deemed to have decided by consensus on a matter submitted for its consideration, if no Member, present at the meeting of the DSB when the decision is taken, formally objects to the proposed decision.'

11 See below nn 26 and 27.

12 Art 2.1. These functions are further elaborated in the DSU. 
panels and the Appellate Body is to determine claims brought under the dispute settlement provisions of the various WTO agreements, but their status is clearly subsidiary to that of the Dispute Settlement Body. Panels, established on an ad hoc basis, are mandated 'to assist the DSB in discharging its responsibilities under this Understanding and the covered agreement', ${ }^{13}$ while the function of the permanent Appellate Body is to ensure that panel reports are legally correct, by hearing appeals on issues of law and legal interpretation. ${ }^{14}$ Significantly, panel and Appellate Body reports have binding force only once they are adopted by the Dispute Settlement Body. ${ }^{15}$

Nor does the existence of a dispute settlement system fundamentally as a whole affect the powers of the political organs. The Ministerial Conference and the General Council retain the exclusive authority to adopt authoritative interpretations of the WTO agreements by three-quarters majority vote, notwithstanding any interpretations given by a panel or the Appellate Body in the context of dispute settlement proceedings between individual WTO Members. ${ }^{16}$ In exceptional circumstances, the Ministerial Conference and the General Council may waive the WTO obligations of any given WTO Member by a three-quarters majority vote. ${ }^{17}$ And they also have the power to submit amendments to the WTO agreements to the Members for acceptance, which usually also requires a three-quarters majority vote. ${ }^{18}$

But if in theory the Ministerial Conference and the General Council are very much the masters of the WTO agreements, in reality their powers are very much reduced by the fact that, according to settled practice, they vote by consensus on every issue. ${ }^{19}$ Shortly after the establishment of the WTO in

13 Art 11 DSU.

14 Art 17.6 DSU.

15 WTO Appellate Body Report Japan-Taxes on Alcoholic Beverages ('Japan-Alcoholic Beverages II'), WT/DS8/AB/R, adopted 1 Nov 1996, para 108 (binding force of panel reports); WTO Appellate Body Report United States-Import Prohibition of Certain Shrimp and Shrimp Products-Recourse to Art 21.1 of the DSU by Malaysia ('US-Shrimp (Art 21.5-Malaysia)'), WT/DS58/AB/RW, adopted 21 Nov 2001, para 109 (Appellate Body reports); WTO Appellate Body Report European Communities-Anti-Dumping Duties on Imports of Cotton-Type Bed Linen From India-Recourse to Art 21.5 by India ('EC-Bed Linen (Art 21.5-India)'), WT/DS141/AB/RW, adopted 24 Apr 2003, para 95 (non-appealed parts of a panel report). It is only on adoption that panel and Appellate Body reports could establish the basis for a res judicata: J Pauwelyn 'How to Win a World Trade Organization Dispute Based on Non-World Trade Organization Law? Questions of Jurisdiction and Merits' (2003) 37 Journal of World Trade 997 at $1017-19$.

16 Art IX:2 of the WTO Agreement.

17 Art IX:3 of the WTO Agreement. Footnote 4 of the WTO Agreement requires consensus for decisions to grant a waiver with respect to implementation periods.

18 Art X of the WTO Agreement. Certain core obligations can only be amended by consensus vote (Art X:2). Other amendments changing the rights and obligations of WTO Members require a two-thirds majority vote to be binding on those Members that accept the amendment. The Ministerial Council may decide by three-quarters majority vote that Members that do not accept the amendment shall be free to leave the WTO or may remain a Member with the consent of the Ministerial Council (Art X:3).

19 See C-D Ehlermann and L Ehring "WTO Decision-Making Procedures, "Member-Driven" Rule-Making and WTO Consensus-Practices: Are They Adequate?' presented at a conference on Developing Countries in the Doha Round EU1, 2-3 July 2004. 
1995, there were some votes but these occurred in unique circumstances. There was a postal ballot on the accession of Ecuador to the WTO, and this only took place because there were not enough Members present at the meeting to satisfy the rule, set out in Article XII:2 of the WTO Agreement, that decisions on accession be taken by two-thirds of the Members of the WTO. There were similarly postal ballots on certain waivers. ${ }^{20}$ In order to prevent a recurrence of this situation, the General Council subsequently decided that decisions on waivers and accessions should in the first instance be taken by consensus, in accordance with Article IX. The decision specified that ' $[\mathrm{t}] \mathrm{he}$ absence of a Member will be assumed to imply that it has no comments on or objections to the proposed decision on the matter. ${ }^{21}$ The question of voting was again raised in 1999, when no consensus could be reached on the candidates for the post of Director-General. A number of Members emphasized the need to avoid establishing any precedent of voting, ${ }^{22}$ and in the end the term was split between the two leading candidates.

The reason for consensus voting is not necessarily that it is popular, but that for both developed and developing WTO Members it is the least bad alternative. Developed countries fear being outvoted, while developing countries fear being presented with faits accomplis. ${ }^{23}$ Indeed, so anxious are developing countries about their position in the WTO that both the Singapore and Doha Ministerial Declarations state expressly that any decision to negotiate on new issues (the so-called 'Singapore issues') must be taken on the basis of explicit consensus. ${ }^{24}$ Mere silence is no longer sufficient. ${ }^{25}$

Of itself, the inability of the political organs to reach difficult decisions damages the credibility of the organization. ${ }^{26}$ However, it becomes even more problematic when seen in the context of an active dispute settlement system, which continues unabated to address issues of great sensitivity. Under the DSU, when it comes to the important decisions to establish a

\footnotetext{
20 The reason for voting is explained in General Council Minutes of Meeting held on 31 July 1995, WT/GC/M/6, 20 Sept 1995.

21 The decision is contained in General Council Minutes of Meeting held on 15 November 1995, WT/GC/M/8, 13 Dec 1995, later circulated as WTO Document WT/L/93.

22 See General Council Minutes of Meeting held on 27 March 1999, WT/GC/M/36/Add 3, 31 Mar 1999.

23 A Narlikar 'The Politics of Participation: Decision-Making Processes and Developing Countries in the World Trade Organization' (2002) 364 The Round Table 171 at 177. See also RH Steinberg 'In the Shadow of Law or Power? Consensus-Based Bargaining and Outcomes in the GATT/WTO’ (2002) 56 International Organization 339.

24 WTO Document Singapore Ministerial Declaration, adopted 13 December 1996, WT/MIN(96)/DEC, 18 December 1996, para 20 (competition and investment) and WTO Document Doha Ministerial Declaration, WT/MIN(01)/DEC/1, 20 November 2001, paras 20, 23, 26 , and 27 (also transparency in government procurement and trade facilitation).

25 For a discussion of the meaning of 'explicit consensus', see WTO Document Comments on the EC Communication (WT/GC/W/491) on the Modalities for the Singapore Issues-Communication from Bangladesh, Cuba, Egypt, India, Indonesia, Kenya, Malaysia, Nigeria, Pakistan, Venezuela, Zambia and Zimbabwe, WT/GC/W/50, 8 July 2003.

26 See Ehlermann and Ehring n 19 above.
} 
panel $^{27}$ or to adopt a panel or Appellate Body report, ${ }^{28}$ it requires a consensus vote to prevent this from taking place. Given that this would mean obtaining the consent of the party standing to lose by the vote, in practice panels are established and reports are adopted automatically. Political stalemate and an active dispute settlement system is truly a recipe for judicial activism.

\section{A TYPOLOGY OF PROPOSED REFORMS}

The deficiencies of the consensus rule and its implications for the balance of power between the political organs and the dispute settlement system have provoked a number of proposals for reform. Some of these have focused on governance in the WTO. For example, Amrita Narlikar has suggested instituting an 'executive board' along the lines of those in the International Financial Institutions, ${ }^{29}$ while Thomas Cottier and Satoko Takenoshita have proposed the introduction of a system of weighted voting, based on each WTO Member's trading power. ${ }^{30}$ However, sensible as these proposals may be in the abstract, they have seemingly attracted little enthusiasm among WTO Members, and there are no signs that voting reform will take place in the foreseeable future.

Others have focused on reasserting political control over panel and Appellate Body reports. All legal systems retain some political control over judicial decisions, whether by legislation or constitutional amendment, and it would be unwise to overlook the fact that, under the present system, a report containing legal reasoning largely (if not exclusively) rejected by the WTO Membership could become part of the WTO legal order. But how to restore some control over panel and Appellate Body reports without politicizing the dispute settlement system is proving to be a difficult challenge.

Within the context of WTO negotiations on DSU reform, there appears to be at least some support for the current proposal of Chile and the United States to allow the Dispute Settlement Body to adopt a panel or Appellate Body report only in part. ${ }^{31}$ On the other hand, there seems to be less interest

\footnotetext{
27 Under Art 6.1 DSU, on request by a complaining Member, panels are established at the second (monthly) meeting of the DSB, unless the DSB decides by consensus not to establish the panel.

${ }^{28}$ See Art 16.4 DSU (adoption of panel reports) and Art 17.14 DSU (adoption of Appellate Body reports).

29 Narlikar, above n 23 at $178-80$.

$30 \mathrm{~T}$ Cottier and S Takenoshita 'The Balance of Power in WTO Decision-Making: Towards Weighted Voting in Legislative Response' (2003) 59 Aussenwirtschaft 171, at 184-6. The authors define trading power in terms of share of trade, Gross Domestic Product, market openness (defined as proportion of imports to GDP) and population.

31 See WTO Document Negotiations on Improvements and Clarifications of the Dispute Settlement Understanding on Improving Flexibility and Member Control in WTO Dispute Settlement-Textual Contribution by Chile and the United States, TN/DS/W/52, 14 Mar 2003, para (c). Partial adoption does not appear to be possible at present, given that Art 16.4 (on panel reports) and Art 17.14 (on Appellate Body reports) refer to the adoption of 'the report' in the
} 
in their additional proposal to use an interim report procedure ${ }^{32}$ to enable disputing parties by common consent to delete findings and the basic rationale behind a finding. ${ }^{33}$ Nor has there been any great enthusiasm for Claude Barfield's suggestion of permitting a panel or Appellate Body report to be blocked by a minority of one-third of WTO Members representing one-quarter of world trade. ${ }^{34}$ Such a mechanism, as a number of distinguished commentators have pointed out, is almost certain to lead to abuse for political ends. ${ }^{35}$ Moreover, if the experience of the pre-1995 GATT system is any guide, this proposal would also place pressure on the dispute settlement organs to craft politically acceptable results at the expense of legal legitimacy. ${ }^{36}$

If it is too risky to abandon the automatic adoption of panel and Appellate Body reports, then what about efforts to limit the types of cases that can be brought to dispute settlement? Along these lines, Claude Barfield has proposed empowering a committee of the DSB or the WTO Director-General to identify certain cases as 'political', or as involving legal issues that are still ambiguous, and then forcing the disputing parties to resolve their differences through political negotiations. ${ }^{37}$ This proposal has also been criticized on the basis that it will be impossible to rule out abuse. ${ }^{38}$ In addition, it might be noted, the proposal risks politicizing the office of the Director-General and the idea that a 'committee' of the DSB should decide on these issues breaks not only with the consensus principle, but even from a system of voting altogether.

But even if the reforms suggested by Barfield have defects, his concerns

singular. The EC has cited Art 16 DSU as a basis for rejecting a suggestion by India for partial adoption of a panel report: see WTO Dispute Settlement Body, Minutes of Meeting held on 5 April 2002, WT/DSB/M/122, 23 Apr 2003, at para 21.

32 Under Art 15 of the DSU, the descriptive parts of panel reports (though not Appellate Body reports) are circulated to the parties to the dispute in advance of a final report. A party to the dispute may request the panel to review parts of the report, but whether the panel does so is within its own discretion.

33 WTO Document TN/DS/W/52, 14 Mar 2003, above n 31. For concerns, see Special Session of the Dispute Settlement Body, Minutes of Meeting held on 16-18 December 2002, TN/DS/M/7, 26 June 2003. Also sceptical is C-D Ehlermann 'Reflections on the Process of Clarification and Improvements of the DSU' in Ortino and Petersmann (ed) The WTO Dispute Settlement System 1995-2003 (The Hague Kluwer 2004) at 106-7.

34 Barfield, above n 3 at 127.

35 RE Hudec 'Review of Barfield, Free Trade, Sovereignty, Democracy: The Future of the World Trade Organization' (2002) 1 World Trade Review 211, at 222; A Stoler 'The WTO Dispute Settlement Process: Did The Negotiators Get What They Wanted? (2004) 3 World Trade Review 99 at 117.

36 On this see RE Hudec 'The Role of the GATT Secretariat in the Evolution of the WTO Dispute Settlement Procedure' in Bhagwati and Hirsch (eds) The Uruguay Round and Beyond: Essays in Honour of Arthur Dunkel (University of Michigan Press 1999).

37 Barfield, above n 3 at 112-13.

38 D Steger 'Book Review: Free Trade, Sovereignty, Democracy: The Future of the World Trade Organization, by Claude E Barfield’ (2002) 5 Journal of International Economic Law 565 at 568. 
merit further consideration. With this aim, the following will look in more detail at some categories of cases that, if decided in dispute settlement proceedings, are not likely to lead to judicial activism.

\section{ARE SOME CASES INHERENTLY INAPPROPRIATE FOR RESOLUTION IN DISPUTE SETTLEMENT PROCEEDINGS?}

\section{A. Cases Involving Politically Sensitive Issues}

\section{1. 'Ordinary' Cases}

Most of the controversial disputes that have so far arisen in the WTO have proved to be so because of the substantive issues which the disputes have involved. Obvious examples are EC-Hormones, in which the Appellate Body rejected a ban on beef treated with artificial growth hormones, ${ }^{39}$ and US-Shrimp, in which the Appellate Body initially ruled unlawful a prohibition on the sale and import of shrimp caught in a manner that harmed sea turtles, before approving a revised, less discriminatory, version of the prohibition. ${ }^{40}$ Though perhaps less in the spotlight, certain rulings on trade remedies (safeguards, antidumping and countervailing measures) have also provoked charges of activism. ${ }^{41}$

For present purposes, the point about these cases is that, though controversial, they have not raised issues of broader institutional significance concerning the powers of the various WTO organs. There may be disagreement with the legal reasoning in these cases, but what has not on the whole been questioned is the appropriateness of the disputes being decided by panels and the Appellate Body. ${ }^{42}$ If the results appear unsatisfactory, this is due to the substantive law applied by panels and the Appellate Body, and it is therefore this law that should be marked for change. ${ }^{43}$

\section{Cases Involving National Security Issues}

Somewhat more complicated are those disputes involving trade measures adopted for reasons of national security, which are permitted under Article

\footnotetext{
39 WTO Appellate Body Report EC Measures Concerning Meat and Meat Products (Hormones) ('EC-Hormones'), WT/DS26/AB/R, adopted 13 Feb 1998.

40 WTO Appellate Body Report United States-Import Prohibition of Certain Shrimp and Shrimp Products ("US-Shrimp'), WT/DS58/AB/R, adopted 6 Nov 1998. The revised ban was allowed in US-Shrimp (Art 21.5-Malaysia) above n 15.

41 Eg by J Greenwald 'WTO Dispute Settlement: An Exercise in Trade Law Legislation?' (2003) 6 Journal of International Economic Law 113.

42 See S Esserman and R Howse 'The WTO on Trial' (2003) 82 Foreign Affairs 130.

43 By amendment under Art X of the WTO Agreement. WTO Members may also renegotiate certain of their individual commitments.
} 
XXI of the GATT and equivalent provisions in other WTO agreements. Here the difficulty is that, despite the preponderance of academic opinion, ${ }^{44}$ some WTO Members continue to maintain that national security disputes are not capable of determination in WTO dispute settlement proceedings. Representative of these views is the statement by Nicaragua in a dispute with Colombia that:

[B]y the very nature of the provisions of Article XXI of the GATT 1994, . . which confirm the inherent right of a State to protect its security and constitute an exception to the multilateral trade rules, these provisions cannot be subjected to an examination by a panel. ${ }^{45}$

This is some irony to this, given that Nicaragua made precisely contrary arguments in disputes with the United States during the 1980s. One might take this as further evidence of the controversial nature of this issue. ${ }^{46}$

There is a substantial literature on the role of Article XXI in WTO dispute settlement proceedings, ${ }^{47}$ and it is necessary here only to give a brief sketch of the main issues: whether a panel has jurisdiction to hear a national security dispute and whether, given a strong 'self-judging' element in the substantive conditions at issue, disputes involving 'political' questions can be considered justiciable. ${ }^{48}$

On the first question, it seems quite clear that panels have at least a potential jurisdiction to hear national security disputes unless this is expressly excluded by agreement of the disputing parties. Article 1.1 of the Dispute Settlement Understanding (DSU) states that " $\mathrm{t}]$ he rules and procedures of this Understanding shall apply to disputes brought pursuant to the consultation and dispute settlement rules and procedures of the . . "covered agreements",'

44 See, eg, D Akande and S Williams 'International Adjudication on National Security Issues: What Role for the WTO?' (2003) 43 Virginia Journal of International Law 365; HL Schloemann and S Ohlhoff " "Constitutionalization" and Dispute Settlement in the WTO: National Security as an Issue of Competence' (1999) 93(2) American Journal of International Law 424 at 441; OQ Swaak-Goldman 'Who Defines Members' Security Interest in the WTO?'(1996) 9 Leiden Journal of International Law 361 at 366; and MJ Hahn 'Vital Interests and the Law of GATT: An Analysis of GATT's Security Exception' (1991) 12 Michigan Journal of International Law 558 at 611 .

45 WTO Document Nicaragua-Measures Affecting Imports from Honduras and Colombia-Statements by Nicaragua, WT/DSB/COM/5/Rev 1, 30 May 2000. This appears also to be the position of the United States. See JH Jackson and AF Lowenfeld 'Helms-Burton, the US, and the WTO,' ASIL Insight, Mar 1997, available at <http://www.asil.org/insight7.htm>.

46 See GATT Panel Report United States-Imports of Sugar from Nicaragua, L/5607, unadopted, 13 Mar 1984 and GATT Panel Report United States-Trade Measures Affecting Nicaragua, L/6053, unadopted, 13 Oct 1986.

47 See above $\mathrm{n} 44$

48 See Frontier Dispute (Burkina Faso/Mali) [1986] ICJ Rep 554 (22 Dec), at para 45, for a discussion of distinction between jurisdiction and justiciability. For an application of this distinction to Art XXI GATT, see Akande and Williams 'International Adjudication on National Security Issues' above n 44. 
Under the GATT, these provisions apply, inter alia, when a WTO Member 'considers that a benefit accruing to it directly or indirectly under the GATT 1994 is being nullified or impaired as a result of . . . the failure of another Member to carry out its obligations', ${ }^{49}$ and there is no exception for measures taken under the national security exception. The availability of dispute settlement is also confirmed by the GATT Decision Concerning Article XXI of the General Agreement, which states that '[w]hen action is taken under Article XXI, all contracting parties affected by such action retain their full rights under the General Agreement.' 50

However, these provisions only demarcate the potential jurisdiction of a panel. The actual jurisdiction of any given panel is determined by its own terms of reference. ${ }^{51}$ The parties may agree to devise their own terms of reference ${ }^{52}$ but unless they agree to do so panels will be governed by the standard terms of reference set out in Article 7.1 DSU. These are as follows:

To examine, in the light of the relevant provisions in (name of the covered agreement(s) cited by the parties to the dispute), the matter referred to the DSB by (name of party) in document ... and to make such findings as will assist the DSB in making the recommendations or in giving the rulings provided for in that/those agreement(s).

When these standard terms of reference apply to a dispute, there can be little question that a panel will have jurisdiction to decide cases in which the validity of a measure adopted for national security reasons is raised. ${ }^{53}$

The second question is whether relevant provisions of Article XXI of GATT (and its equivalents in the other agreements) are by their own terms 'self-judging', and therefore not justiciable by a panel. Article XXI of GATT states, relevantly, that:

Nothing in this Agreement shall be construed: . . . (b) to prevent any contracting party from taking any action which it considers necessary for the protection

\footnotetext{
49 Art XXIII GATT.

50 GATT Document Decision Concerning Art XXI of the General Agreement, Decision of 30 Nov 1982, L/5426, BISD 29S/23. This Decision forms part of the GATT 1994 under para 1(b)(iv) of the language incorporating the GATT 1994 into the WTO Agreement, as it was intended to be binding on all of the Contracting Parties. On this requirement see WTO Appellate Body Report United States-Tax Treatment for 'Foreign Sales Corporations' ('US-FSC'), WT/DS108/AB/R, adopted 20 Mar 2000, para 108.

51 WTO Appellate Body Report Brazil-Measures Affecting Desiccated Coconut ('Brazil-Desiccated Coconut'), WT/DS22/AB/R, adopted 20 Mar 1997, at 18.

52 This was done to exclude certain national security issues in the Nicaragua/US GATT panel reports noted above $\mathrm{n} 46$.

53 In Oil Platforms, Preliminary Objections, Judgment [1996] ICJ Rep 804 (12 Dec), the International Court of Justice considered a national security provision reading as follows: ' $[\mathrm{t}] \mathrm{he}$ present Treaty shall not preclude the application of measures: . . . necessary to protect its essential security interests'. The Court concluded that this provision 'does not restrict its jurisdiction in the present case, but is confined to affording the Parties a possible defence on the merits to be used should the occasion arise' (para 20).
} 
of its essential security interests ... (iii) taken in time of war or other emergency in international relations; . . .54

A panel must pay close attention to the opinion of a WTO Member as to whether a measure is necessary, but this provision still contains at least some judicially manageable standards. At a minimum, a panel will be able to determine the objective question of whether there is a 'war' or 'other emergency in international relations'. ${ }^{55}$ A panel may also be able to determine whether the WTO Member concerned does, in fact, consider it necessary to take the measures at issue. In this context, a standard of good faith may be relevant, ${ }^{56}$ as may a consideration of whether the measure is 'necessary'. 57

In short, there is nothing about an invocation of Article XXI that necessarily takes it beyond the purview of a panel, either as a question of jurisdiction or one of justiciability.

\section{B. Cases Where the Law is Indeterminate}

If the subject matter of disputes does not pose any inherent problems for WTO dispute settlement, the same cannot necessarily be said of disputes in which the underlying law is indeterminate. Indeterminacy is, of course, a feature common to all legal systems - and probably inherent in them as well-but it is particularly marked in the WTO, where the substantive agreements are especially characterized by gaps, overlaps, and conflicts. A number of reasons have been advanced to explain this state of affairs. One is that the agreements were originally negotiated in parallel, the original intention being that they would operate as autonomous agreements. ${ }^{58}$ Another is that the Uruguay Round negotiators, often not lawyers themselves, ${ }^{59}$ worked without sufficient legal vetting of the results. ${ }^{60}$ In any case, regardless of the cause, it is increasingly likely that a panel or the Appellate Body will be faced with a

54 Emphasis added.

55 V Heiskanen 'International Sanctions and GATT Obligations' in Hakapää et al (ed) Essays on International Law (Helsinki Finnish Branch of the International Law Association 1987) at 86; Akande and Williams, above n 44 at 399-402.

56 Akande and Williams, above n 44 at 389-94 (also discussing problems with a 'good faith' test).

$57 \mathrm{Cf}$ the 'necessity' test in Art XX, as described by WTO Appellate Body Report Korea-Measures Affecting Imports of Fresh, Chilled and Frozen Beef, WT/DS161/AB/R, adopted 10 Jan 2001, para 162 and in WTO Appellate Body Report EC-Asbestos, above n 1 at para 172. See also Akande and Williams, above n 44 at 394-6.

58 J Pauwelyn Conflict of Norms in Public International Law: How WTO Law Relates to Other Rules of International Law (Cambridge CUP 2003) at 23-4.

59 See JHH Weiler 'The Rule of Lawyers and the Ethos of Diplomats: Reflections on the Internal and External Legitimacy of WTO Dispute Settlement' (2002) 35 Journal of World Trade 191.

60 This has led one former Director of the WTO Legal Affairs Division to advance the 'modest proposal' that a legal drafting group be made available in order to minimize 'surprises' from any texts adopted in the Doha Round of negotiations. See PJ Kuijper 'A Legal Drafting Group for the Doha Round: A Modest Proposal' (2003) 37 Journal of World Trade 1031. 
genuine and unavoidable indeterminacy in the applicable law. Indeed, in some cases such indeterminacy has arguably already arisen, though the Appellate Body has so far been able to avoid having to pronounce on the issue directly. ${ }^{61}$ So how might such a situation be resolved?

\section{Authoritative Interpretation}

According to the text of the Dispute Settlement Understanding, the solution in cases of indeterminacy is to resort to the General Council. Article 3.9 of the DSU states that ' $[\mathrm{t}]$ he provisions of this Understanding are without prejudice to the rights of Members to seek authoritative interpretation of provisions of a covered agreement through decision-making under the WTO Agreement.' This is a clear reference to Article IX:2 of the WTO Agreement, which states, relevantly, that ' $[t]$ he Ministerial Conference and the General Council shall have the exclusive authority to adopt interpretations of this Agreement and of the Multilateral Trade Agreements [by three-fourths vote]. ${ }^{62}$

In any case, the practical problem with this mechanism is that the practice of voting by consensus seems to apply also to authoritative interpretations under Article IX:2. ${ }^{63}$ Until voting becomes a reality, this political solution will therefore remain a dead letter. ${ }^{64}$

61 See WTO Appellate Body Report United States-Import Measures on Certain Products from the European Communities ('US-Certain EC Products'), WT/DS165/AB/R, adopted 10 Jan 2001, para 92 and WTO Appellate Body Report United States-Anti-Dumping Measures on Certain Hot-Rolled Steel Products from Japan ('US-Hot Rolled Steel'), WT/DS184/AB/R, adopted 23 Aug 2001, para 125. See also GATT Panel Report European Economic Community-Subsidies on Exports of Wheat Flour, SCM/42, BISD 31S/259, unadopted, 21 Mar 1983, para 5.3, where the panel said that 'it was unable to conclude as to whether the increased share has resulted in the EEC "having more than an equitable share" in terms of Art 10 [of the SCM Code] in light of . . . most importantly, the difficulties inherent in the concept of "more than equitable share".' J Pauwelyn 'Cross-Agreement Complaints Before the Appellate Body: A Case Study of the EC-Asbestos Dispute' (2002) 1 World Trade Review 167, considers that the Appellate Body declared a non liquet in refusing to decide on a claim under the TBT Agreement in WTO Appelate Body Report EC-Asbestos, above n 1. However, this can also be explained on the basis that the panel had made no legal findings under the TBT Agreement and therefore the Appellate Body had no jurisdiction to entertain these claims.

${ }^{62}$ It may be noted that Article 3.9 does not, on its face, add much to the rights of WTO Members under the WTO Agreement, given that in any case the WTO Agreement prevails over the DSU in the event of any conflict. Art XVI:3 of the WTO Agreement. Art II:2 of the WTO Agreement somewhat confusingly deems the DSU to be one of the 'Multilateral Trade Agreements' to which this conflicts rule applies.

63 There has only once even been an attempt to obtain an authoritative interpretation. This was to resolve the 'sequencing' issue on the relationship between Art 21.5 and 22.2 of the DSU. See WTO Document Request for an Authoritative Interpretation Pursuant to Art IX:2 of the Marrakesh Agreement Establishing the World Trade Organization-Communication from the European Communities, WT/GC/W/133, 25 Jan 1999. Likewise, there has been only one proposal to use Art X to amend the WTO Agreements, on the same issue. See WTO Document Proposal to Amend Certain Provisions of the Understanding on Rules and Procedures Governing the Settlement of Disputes (DSU) Pursuant to Art X of the Marrakesh Agreement Establishing the World Trade Organization-Submission by Bolivia, Canada, Chile, Colombia, Costa Rica, 


\section{Non liquet}

Given the unlikelihood, on current form, of an authoritative interpretation, it is appropriate to consider another solution to the problem of an indeterminacy in the law applicable to a dispute. This is the possibility that panels and the Appellate Body may be entitled to decline to give a decision on the basis that the law is unclear: in other words, to declare a non liquet. ${ }^{65}$

\section{- Non liquet in international law}

For a panel or the Appellate Body to declare a non liquet is likely to be controversial, given the strong presumption that this is prohibited under the normal principles of international law. Sir Hersch Lauterpacht, who wrote forcefully in support of a prohibition on declarations of non liquet, called this 'one of the most undisputably established rules of positive international law as evidenced by an uninterrupted continuity of international arbitral and judicial practice'. ${ }^{66}$ However, there are contrary views, of which perhaps the best known is that expressed by Julius Stone, for whom practice, principle, and policy all led to the conclusion that, while a tribunal is not compelled to declare a non liquet in cases where the law is unclear, neither is it prohibited from doing so. ${ }^{67}$ Recently the International Court of Justice appeared to declare a non liquet in its Advisory Opinion on the Legality of the Threat or Use of Nuclear Weapons, when it stated that:

$[\mathrm{I}] \mathrm{n}$ view of the current state of international law, and of the elements at its

Ecuador, Japan, Korea, New Zealand, Norway, Peru, Switzerland, Uruguay and Venezuela for Examination and Further Consideration by the General Council, WT/GC/W/410/Rev.1, 26 Oct 2001.

64 In the context of negotiations on DSU reform, Jordan has proposed adding a new Art 5 bis to the DSU, according to which parties and third parties to a dispute would be entitled to refer questions of interpretation to the General Council (which adds nothing to Art 3.9) and additionally would 'follow the form, time-frame and other guidelines set by the General Council for this purpose'. This might allow for suspension of the DSU time limits. See WTO Document Jordan's Contributions Towards the Improvement and Clarification of the WTO Dispute Settlement Understanding, TN/DS/W/43, 28 Jan 2003.

65 It is relevant to note a proposal made by Kenya, according to which Art 3.2 DSU would be amended by adding the following paragraph: '[w]hen, in the course of proceedings before a panel or the Appellate Body, a question arises on whether or not there is a conflict between provisions of any covered Agreement or between any covered Agreements, the panel or Appellate Body shall refer the matter to the General Council for a determination. In reaching the determination, the General Council may exercise the authority conferred under paragraph 2 of Art IX of the WTO Agreement.' See WTO Document Text for the African Group Proposals on Dispute Settlement Understanding Negotiations-Communication from Kenya, TN/DS/W/42, 24 Jan 2003. A similar proposal was made in GATT Document Draft Final Act Embodying the Results of the Uruguay Round of Multilateral Trade Negotiations, MTN.TNC/W/FA, 20 Dec 1991, at T.3.

66 H Lauterpacht 'Some Observations on the Prohibition of Non Liquet and the Competeness of the Law' in van Asbeck et al (eds) Symbolae Verzijl (The Hague 1958) at 200.

67 J Stone 'Non Liquet and the Function of Law in the International Community' (1959) 35 British Yearbook of International Law 124. 
disposal, the Court cannot conclude definitively whether the threat or use of nuclear weapons would be lawful or unlawful in an extreme circumstance of self-defence, in which the very survival of a State would be at stake. ${ }^{68}$

There are a number of justifications for a prohibition on declarations of non liquet. One such justification is that the law is necessarily complete, either because it is logically complete, or because general principles are available to fill any gaps, or because of the 'adversarial principle' that, in the absence of a demonstrated rule favouring the claim of the applicant, judgment must be for the respondent. ${ }^{69}$ Another is that tribunals are bound by 'the necessity to abide by the will of the parties to resort to the judicial settlement of their dispute'. ${ }^{70}$ This article will refrain from engaging with the first set of reasons, though it may be suggested that the present philosophical climate does not favour the idea of complete systems of any kind. Rather, it will explore the application to the WTO of the second rationale, by looking at the extent to which the Dispute Settlement Understanding, as an expression of the 'will' of WTO Members, imposes a duty on panels and the Appellate Body necessarily to decide all disputes arising before them and over which they have jurisdiction.

- Non liquet under the Dispute Settlement Understanding

The Dispute Settlement Understanding makes it clear, in the first place, that disputes arising under the covered agreements are to be solved within the WTO dispute settlement system. Article 3.2 of the DSU states, inter alia, that:

The Members recognize that it [the dispute settlement system] serves to preserve the rights and obligations of Members under the covered agreements, and to clarify the existing provisions of those agreements in accordance with customary rules of interpretation of public international law.

This is reinforced by the exclusive jurisdiction clause in Article 23 of the DSU, which states that:

When Members seek the redress of a violation of obligations or other nullification or impairment of benefits under the covered agreements or an impediment to the attainment of any objective of the covered agreements, they shall have recourse to, and abide by, the rules and procedures of this Understanding. ${ }^{71}$

${ }^{68}$ Legality of the Threat or Use of Nuclear Weapons, Advisory Opinion requested by the General Assembly, [1996] ICJ Rep 226 (8 Jul), para 105(2)(E). For criticism of this ruling, see especially the Dissenting Opinions of Judges Schwebel, Higgins and Koroma.

69 See Stone, above n 67 at 133-7 and P Weil 'The Court Cannot Conclude Definitively . . . Non Liquet Revisited' (1997) 36 Columbia Journal of Transational Law 109 at 110-13.

${ }^{70}$ Ibid at 119.

71 See WTO Panel Report United States-Sections 301-310 of the Trade Act of 1974 ('US-Section 301'), WT/DS152/R, adopted 27 Jan 2000, at para 7.43 (describing Art 23(1) as an 'exclusive dispute resolution clause'). Y Shany The Competing Jurisdictions of International 
On the other hand, neither of these provisions requires panels or the Appellate Body to reach a decision even in situations in which the underlying law is indeterminate. They speak of the dispute settlement system as a whole, and, as mentioned, responsibility for the administration of this system rests not with panels or the Appellate Body, but rather with the Dispute Settlement Body. So ultimately it is the Dispute Settlement Body that has the responsibility of finding a solution in cases where the law is unclear. ${ }^{72}$ In order to determine the responsibility of panels and the Appellate Body to decide cases, it is therefore necessary to look at the relevant provisions in the DSU setting out their duties and functions.

The function of panels is set out in Article 11, which states as follows:

The function of panels is to assist the DSB in discharging its responsibilities under this Understanding and the covered agreements. Accordingly, a panel should make an objective assessment of the matter before it, including an objective assessment of the facts of the case and the applicability of and conformity with the relevant covered agreements, and make such other findings as will assist the DSB in making the recommendations or in giving the rulings provided for in the covered agreements. ${ }^{73}$

The clear message of this provision is that panels have a duty only to make findings that will assist the DSB in making its recommendations and rulings. This message is reflected also in Article 7.1 of the DSU, which sets out the standard terms of reference for a panel, and which requires a panel 'to make such findings as will assist the DSB in making the recommendations or in giving the rulings provided for in that/those agreement(s) ${ }^{74}$ It seems to follow that for a panel to make a ruling that would not assist the DSB would not only be improper, but possibly even ultra vires.

Could it be said that a panel has the power to determine when a finding would or would not assist the DSB? To this one can give a relatively certain answer: as the Appellate Body has held, panels have the jurisdiction to determine their own jurisdiction (a Kompetenz-Kompetenz). ${ }^{75}$ If so, then the only

Courts and Tribunals (Oxford OUP 2003), at 184, notes several caveats to the view that Art 23 can be considered an exclusive jurisdiction clause: first, that the DSU permits arbitration, though subject to DSB review; second, that it applies only to determinations, not to 'interpretations' of the WTO agreements; and third, that it does not prejudge the determination of disputes in another legal forum, such as under regional trade agreements, so long as it is accepted that they do not produce res judicata effects within the WTO. In the opinion of the present author, this third caveat is unfounded. See on this point G Marceau 'The Dispute Settlement Rules of the North American Free Trade Agreement: A Thematic Comparison with the Dispute Settlement Rules of the World Trade Organization' in Petersmann (ed) International Trade Law and the GATT/WTO Dispute Settlement System (The Hague Kluwer 1997) at 534.

72 For this reason it may be suggested that the DSU be amended to allow the Dispute Settlement Body, as an organ, to refer matters to the General Council for authoritative interpretation under Art IX:2.

73 Emphasis added. $\quad{ }^{74}$ Emphasis added.

75 WTO Appellate Body Report Mexico-Anti-Dumping Investigation of High Fructose Corn Syrup (HFCS) from the United States-Recourse to Art 21.5 of the DSU by the United States ('Mexico-Corn Syrup (Art 21.5-US)'), WT/DS132/AB/RW, adopted 21 Nov 2001, at para 37. 
question would be whether a finding based on indeterminate law could be said to be of no assistance to the DSB in making its recommendations and rulings. If not, then arguably no such finding should be made.

There are, however, two other provisions that seem to contradict the notion that panels and the Appellate Body may declare a non liquet. Article 7.2 DSU states that '[p]anels shall address the relevant provisions in any covered agreement or agreements cited by the parties to the dispute'. In the same vein, Article 17.12 DSU requires the Appellate Body to 'address each of the issues' raised on appeal.

If one accepts the extra-curial words of two former Chairmen of the Appellate Body, these provisions must be taken seriously. James Bacchus has said that because of Article 17.12 'once the parties to a dispute decide to appeal a legal issue to the Appellate Body for a final ruling, we seven [Appellate Body members] have absolutely no authority not to rule on that issue'. ${ }^{76}$ Similarly, Claus-Dieter Ehlermann has said that '[n]either a panel nor the Appellate Body is entitled to refuse to address a claim because the panelists or the Appellate Body members want to avoid deciding a legal question that has delicate political consequences'. ${ }^{77}$

And yet it is clear that these provisions have not in practice required panels or the Appellate Body to decide on every single issue arising before them. The Appellate Body has made it quite clear that panels are entitled to exercise 'judicial economy'. This, as explained by the Appellate Body in Australia-Salmon, means that:

[A] panel has to address those claims on which a finding is necessary in order to enable the DSB to make sufficiently precise recommendations and rulings so as to allow for prompt compliance by a Member with those recommendations and rulings 'in order to ensure effective resolution of disputes to the benefit of all Members'. ${ }^{78}$

This confirms the proposition that a panel is obliged to make decisions only when this will assist the DSB in the exercise of its responsibilities. ${ }^{79}$

\footnotetext{
$76 \mathrm{~J}$ Bacchus 'The Bicycle Club: Affirming the American Interest in the Future of the WTO' (2003) 37 Journal of World Trade 429 at 439.

77 C-D Ehlermann 'Tensions between the Dispute Settlement Process and the Diplomatic and Treaty-Making Activities of the WTO' (2002) 1(3) World Trade Review 301 at 305 (citing for this proposition both Arts 17.12 and 3.2 DSU).

78 WTO Appellate Body Report Australia-Measures Affecting the Importation of Salmon ('Australia-Salmon'), WT/DS18/AB/R, adopted 6 Nov 1998, at para 233.

79 There is a risk involved in the exercise of judicial economy, as noted by PC Mavroidis 'Judicial Supremacy, Judicial Restraint, and the Issue of Consistency of Preferential Trade Agreements with the WTO: The Apple in the Picture' in Kennedy and Southwick (eds) The Political Economy of International Trade Law; Essays in Honor of Robert E. Hudec (Cambridge CUP 2003) at 596. The danger is that panels will leave the Appellate Body with insufficient factual evidence to 'complete the analysis' in the event that it overturns the panel's other findings. Consequently, Mavroidis notes, panels have more recently tended to address all issues before them.
} 
Nor has Article 17.12 required the Appellate Body to address every issue on appeal. In a telling passage in Japan-Agricultural Products, the Appellate Body expressly said that, because it had already reversed the panel on one issue, 'there is no need to address [an] issue' that earlier in its report it had listed as one of the 'issues raised on appeal' ${ }^{80}$ The principle of judicial economy applies to the Appellate Body as well.

In light of this, it seems reasonable to suggest that, where the law is indeterminate, panels and the Appellate Body will be discharging their duties to 'address' the relevant provisions of the covered agreements, and the relevant legal issues, by making a statement to this effect. Furthermore, it may be suggested, such a statement may be a more appropriate means of fulfilling their duty to assist the Dispute Settlement Body than a finding based on law that, in truth, is indeterminate. Such a proposition is supported by the positive law set out in the Dispute Settlement Understanding, and it may serve as a useful safety valve for at least some of the tensions between the WTO's political and quasi-judicial organs.

\section{Cases Involving Questions of 'Institutional Balance'}

A third category of controversial disputes involves issues that might be considered inappropriate for determination by a panel or the Appellate Body, on the basis that such a decision would interfere unduly with the powers of the WTO political organs. This question of 'institutional balance', which had been an issue under the GATT system, ${ }^{81}$ first came before the Appellate Body in two virtually simultaneous disputes in 1999.

\section{India-Quantitative Restrictions and Turkey-Textiles}

The first of these cases was India-Quantitative Restrictions, ${ }^{82}$ which concerned a challenge to trade restrictions maintained by India, otherwise in conflict with the GATT, but justified by India under an exception to the GATT applicable to measures taken for balance of payments reasons. The panel's jurisdiction to decide on the claim was based on footnote 1 of the Understanding on Balance of Payments, which states that ' $[\mathrm{t}]$ he provisions of Articles XXII and XXIII of GATT 1994 as elaborated and applied by the

80 WTO Appellate Body Report Japan-Measures Affecting Agricultural Products ('Japan-Agricultural Products'), WT/DS76/AB/R, adopted 19 Mar 1999, para 143, issue (d). Compare issue (d) in para 71 (issues raised on appeal).

81 See GATT Panel Report European Community Tariff Treatment on Imports of Citrus Products from Certain Countries in the Mediterranean Region, L/5776, unadopted, 7 Feb 1985 , and GATT Panel Report EEC-Member States' Import Regimes for Bananas, DS32/R, unadopted, 3 June 1993.

82 WTO Appellate Body Report India-Quantitative Restrictions on Imports of Agricultural, Textile and Industrial Products ('India-Quantitative Restrictions'), WT/DS90/AB/R, adopted 22 Sept 1999. 
Dispute Settlement Understanding may be invoked with respect to any matters arising from the application of restrictive import measures taken for Balance-of-Payments purposes.'

The question of institutional balance arose because of the concurrent power of two WTO political organs, the General Council and the Balance of Payments Committee, to make recommendations with respect to trade measures taken for balance of payments reasons. The BOP Committee is mandated to undertake a review of such measures, to propose alternative measures, and to propose time-frames for phasing out unjustified balance of payments restrictions which would otherwise be inconsistent with the GATT. It makes recommendations to the General Council, although if no consensus is reached, the Committee simply reports on the different views expressed in the Committee. ${ }^{83}$ The General Council may recommend that, in adhering to such a time-schedule, a Member shall be deemed to be in compliance with its GATT 1994 obligations. ${ }^{84}$

India, the defendant, began by contesting the jurisdiction of the panel to determine the justification of its balance of payments measures under footnote 1 of the BOP Understanding. The Appellate Body rejected this argument, stating that the words 'any matters', 'arising from' and 'application' were amply sufficient to cover the question of the justification of India's balance of payments measures. ${ }^{85}$ There can be little dispute that this was the correct decision.

Next, India claimed that 'there is a principle of institutional balance which requires panels, in determining the scope of their competence, to take into account the competence conferred upon other organs of the WTO'. ${ }^{86}$ While the reference to 'competence' hints that this point was intended to be an additional argument on jurisdiction, in reality it is better understood in terms of justiciability. In any case, this argument was also rejected by both the panel and the Appellate Body, which noted that 'the BOP Committee and panels have different functions, and that the BOP Committee procedures and the dispute settlement procedures differ in nature, scope, timing and type of outcome'. 87

The Appellate Body's rejection of the principle of 'institutional balance' in India-Quantitative Restrictions found its way, via an obiter dictum, into its almost contemporaneous report on Turkey-Textiles. ${ }^{88}$ This case concerned

\footnotetext{
83 Art XVIII:B of GATT Understanding on the Balance-of-Payments Provisions of the General Agreement on Tariffs and Trade 1994 paras 5-12 (consultations) and 13 (report to General Council).

${ }^{84}$ BOP Understanding para 13. This paragraph also states that ' $[\mathrm{w}]$ henever the General Council has made specific recommendations, the rights and obligations of Members shall be assessed in the light of such recommendations.'

85 India-Quantitative Restrictions above n 82 at paras 89-95.

86 Ibid at para 98.

87 Ibid at para 104.

88 WTO Appellate Body Report Turkey-Restrictions on Imports of Textile and Clothing Products ('Turkey-Textiles'), WT/DS34/AB/R, adopted 19 Nov 1999.
} 
the question whether a panel has the power to determine the GATT consistency of a measure taken under regional trade agreement, ${ }^{89}$ in light of the power of the WTO Committee on Regional Trade Agreements (CRTA) to make determinations on the WTO compatibility of regional trade agreements. ${ }^{90}$

As mentioned, the issue in Turkey-Textiles concerned the legality of a measure taken under a regional trade agreement, but the Appellate Body only narrowly avoided pronouncing directly on the more sensitive question whether a panel has jurisdiction to determine the legality of the regional trade agreement itself. ${ }^{91}$ Nevertheless, its reference to its earlier finding leaves little doubt that it would answer this question in the affirmative. ${ }^{92}$ It said:

We are not called upon in this appeal to address this issue, but we note in this respect our ruling in India-Quantitative Restrictions on Imports of Agricultural, Textile and Industrial Products on the jurisdiction of panels to review the justification of balance-of-payments restrictions under Article XVIII:B of the GATT $1994 . .^{93}$

This raises the prospect of a WTO panel determining whether an entity such as the EC or NAFTA meets the strict conditions set out in Article XXIV of the GATT or Article V of GATS.

The obvious sensitivity of disputes involving regional trade agreements and balance of payments issues has led some to question the wisdom of initiating these disputes in the first place. ${ }^{94}$ However, the reasoning of the Appellate Body has not, on the whole, provoked much academic criticism. ${ }^{95}$ The major exception is Frieder Roessler, who has objected to these decisions

89 Similar to footnote 1 of the BOP Understanding, para 12 of the Understanding on Art XXIV of the General Agreement on Tariffs and Trade 1994 provides that '[t]he provisions of Arts XXII and XXIII of GATT 1994 as elaborated and applied by the Dispute Settlement Understanding may be invoked with respect to any matters arising from the application of those provisions of Art XXIV relating to customs unions [or] free-trade areas ....

90 Review of regional trade agreements was undertaken by Working Parties under Art XXIV:7(a) GATT, and para 7 of the Understanding on the Interpretation of Art XXIV. This function is now performed by the CRTA pursuant to WTO General Council Committee on Regional Trade Agreements, Decision of 6 Feb 1996, WT/L/127.

91 During the Uruguay Round the EC unsuccessfully proposed adding the following sentence to these provisions: 'Such recourse to the dispute settlement provisions, however, shall not be allowed to question the conformity with GATT of existing customs unions, [or] free-trade areas . . . as long as the CONTRACTING PARTIES have not made a specific recommendation under Art XXIV:7 of the General Agreement'. See Communication from the European Communities, MTN.TNC/W/125, 13 Dec 1993.

92 In accord, Ehlermann, above n 77 at 303; G Marceau and C Reiman 'When and How Is a Regional Trade Agreement Compatible with the WTO?' (2001) 28 Legal Issues of Economic Integration 297 at 313; F Roessler 'The Institutional Balance between the Judicial and the Political Organs of the WTO' in Bronckers and Quick (eds) New Directions in International Economic Law: Essays in Honour of John H Jackson (The Hague Kluwer 2000) at 338.

93 Turkey-Textiles, above n 88 at para 60.

94 Ehlermann, above $\mathrm{n} 77$ at 306.

95 Cf Mavroidis, above n 79 and WJ Davey 'Has the WTO Dispute Settlement System Exceeded Its Authority?' (2001) 4 Journal of International Economic Law 79 at 85-8. 
on a number of grounds, and whose arguments will therefore be taken as a platform for examining the relevant institutional issues.

Roessler begins by challenging the Appellate Body's findings that panels have jurisdiction to determine the matters at issue in these two cases. Based on Article 31 of the Vienna Convention, Roessler argues that, in determining the scope of the provisions under which it exercises jurisdiction, ${ }^{96}$ a panel should take into account the 'context' of those provisions, meaning the existence of other attributed powers under the WTO Agreement. ${ }^{97}$ But while the context of a jurisdictional provision is certainly relevant to interpreting its scope, ${ }^{98}$ the existence of a merely concurrent power over a particular matter cannot of itself be seen as a factor limiting jurisdiction. At most, this might raise a question of justiciability.

Secondly, Roessler argues that panels are incompetent to determine the matters in dispute in these cases because there are no 'agreed standards for determining the adequacy of monetary reserves [in the case of balance of payments restrictions] and the scope of trade integration . . . has deliberately been left undefined.' ${ }^{99}$ On the facts of India-Quantitative Restrictions and Turkey-Textiles this is a questionable claim. ${ }^{100}$ But the broader issue is certainly valid, namely, whether panels or the Appellate Body are obliged to decide cases where the law is indeterminate, or whether they are entitled to declare a non liquet.

Thirdly, Roessler points to the relationship between the political and dispute settlement procedures at issue, arguing that the availability of panel proceedings might reduce the incentives of another party to reach consensus in the political forum. ${ }^{101}$ In itself, this is not legally relevant, and indeed, the absence of dispute settlement would give free rein to the defendant to maintain its restrictions with no possibility of review. ${ }^{102}$ What is legally relevant - and this is the nub of the issue - is Roessler's additional claim that the resolution of a dispute in judicial proceedings would render useless the exercise of the powers of the political organs. ${ }^{103}$ This is the heart of the institutional balance issue, and yet the reasoning of both the panel and the Appellate Body on this point is disappointing.

\footnotetext{
96 On this see above $\mathrm{n} 75$.

97 Roessler, above $\mathrm{n} 90$ at 340.

98 See, eg, Oil Platforms, Preliminary Objections, Judgment [1996] ICJ Rep 803 (12 Dec) and the Separate Opinion of Judge Higgins.

99 Roessler, above n 92 at 344.

100 Davey, above n 95 at 87, states that a panel can determine whether or not balance of payments measures are justified with the aid of advice from the IMF, while acknowledging the greater complexities involved in any determination by panels of the legality of regional trade agreements. In support of panel review in the case of regional trade agreements, see Mavroidis, above $\mathrm{n} 77$.

101 Roessler, above n 92 at 342.

102 Davey, above n 95 at 87 and Mavroidis, above n 79 at 595

103 Roessler, above n 92 at 342.
} 
The Appellate Body declared itself satisfied with the panel's finding that the competing political and quasi-judicial procedures differed in nature, scope, timing and type of outcome', but it failed to analyse the matter in any detail. ${ }^{104}$ This is regrettable, because the panel itself failed to give a sound explanation as to the precise differences between the competing procedures at issue in this case. It stated merely that 'the BOP Committee is called upon to address a wider range of issues than panels' and that it was foreseen that recourse to dispute settlement would be available in respect of balance of payments measures. ${ }^{105}$ The first of these statements may be relevant in those cases where the competence of the BOP Committee exceeds that of panels, but it does not have any bearing on those issues on which there is an overlap. The second statement simply restates the issue as a conclusion. Both statements are unsatisfactory as a basis for determining that panels are required to address issues over which the political organs have concurrent jurisdiction.

It is, however, possible to flesh out this reasoning by reference to other parts of the panel report, which give additional clues as to why the panel was so certain that the political and quasi-judicial procedures for resolving balance of payments disputes could co-exist. One consideration seems to have been that justifications for trade restrictions for balance of payments reasons are not fixed in time. As the panel said, '[e]ven if this Panel were to decide that India's measures are not justified, nothing would prevent the Committee and the General Council from reaching different conclusions on the basis of new, different facts. ${ }^{\prime} 106$ The panel also discounted the possibility of any conflicts between panel rulings and decisions of the political organs. The panel noted that the General Council retains its power under Article IX:3 of the WTO Agreement to waive India's obligations, as determined by any prior panel, ${ }^{107}$ and that, in the event of conclusions being reached by the General Council, these will be taken into account by any future panel. ${ }^{108}$ Indeed, in the case of balance of payments restrictions this is required by paragraph 13 of the BOP Understanding, which states that ' $[w]$ henever the General Council has made specific recommendations, the rights and obligations of Members shall be assessed in the light of such recommendations.'

But this leaves a number of difficulties. For example, by referring to the possibility of waivers, the panel implies that, on the same facts, the BOP Committee and the General Council would be precluded from reaching a result opposite to that reached already by a panel. This seems to amount to a reduction in the powers of these organs. In addition, while under paragraph

104 India Quantitative Restrictions above n 82 at para 104.

105 WTO Panel Report India-Quantitative Restrictions on Imports of Agricultural, Textile and Industrial Products, WT/DS90/R, adopted 22 Sept 1999, para 5.90.

106 Ibid para 5.93.

107 Ibid. The panel ignores the condition in Art IX:3 of the WTO Agreement that a waiver be granted only 'in exceptional circumstances' and kept under review.

108 Ibid para 5.94 
13 of the BOP Understanding a panel is bound to respect the decision of the General Council in matters concerning balance of payments restrictions, this may not necessarily apply to CRTA decisions on regional trade agreements. The legal status of such decisions is entirely unclear, and it is far from certain that a panel would consider any such decision to be binding on it. ${ }^{109}$

Superficially, some support for the conclusions reached by the panel and the Appellate Body may be found in the rulings of the International Court of Justice that the Court may not decline jurisdiction simply because a political organ (the Security Council) has a concurrent power with respect to the matter in dispute. In the Nicaragua case the Court said that '[t]he [Security] Council has functions of a political nature assigned to it, whereas the Court exercises purely judicial functions. Both organs can therefore perform their separate but complementary functions with respect to the same events.' 110

But even this statement, quoted in later cases, ${ }^{111}$ is not free from difficulty. It has been pointed out that until the Lockerbie case, in all of the cases concerning the 'complementary' functions of the ICJ and the Security Council, the parallel claims in both forums were brought by the same party with the same objectives. ${ }^{112}$ It remains an open question whether, in all cases, the Court would pronounce on an issue if that would impair the powers of the political organs of the United Nations. ${ }^{113}$

\section{Resuscitating Institutional Balance: Two Difficult Situations}

One might suggest that there are at least two situations in which, for reasons of institutional balance, it may be necessary for a tribunal to refrain from exercising its jurisdiction. The first is when another authority has not only concurrent but also exclusive jurisdiction over a matter. ${ }^{114}$ Authority for this

109 Mavroidis, above $\mathrm{n} 79$ at 597, expresses the view that a panel would respect the decision of the CRTA.

110 Military and Paramilitary Activities in and against Nicaragua (Nicaragua/US), Jurisdiction and Admissibility, Judgment [1984] ICJ Rep 392 (26 Nov), at para 95.

111 Eg Case Concerning Application of the Convention on the Prevention and Punishment of the Crime of Genocide (Bosnia and Herzegovina/Yugoslavia (Serbia and Montenegro), Provisional Measures, Order [1993] ICJ Rep 3 (8 Apr) para 33.

112 D Akande 'The International Court of Justice and the Security Council: Is There Room for Judicial Control of the Political Organs of the United Nations' (1997) 46 ICLQ 309 at 313.

113 Ibid at 313; see also V Gowlland-Debbas 'The Relationship Between the International Court of Justice and the Security Council in Light of the Lockerbie case' (1994) 88 AJIL 643 and C Gray 'The Use and Abuse of the International Court of Justice: Cases Concerning the Use of Force after Nicaragua' (2003) 14 EJIL 867.

114 Exclusivity does not seem to be required in the context of competing judicial proceedings (and nor does it so far seem to be conclusive). Here the situation is usually analysed in terms of the doctrine of litis pendens, which entitles a tribunal, on certain conditions, to decline to exercise its jurisdiction when there is a danger of conflicting judgments. The conditions are an identity of parties, matters in dispute, object of proceedings (Polish Upper Silesia (Jurisdiction) [1925] PCIJ Ser A, No 6, at 19-20) and remedies (The Factory at Chorzów (Germany/Poland) (Claim for Indemnity) (Jurisdiction) [1927] PCIJ Ser A, No 9, at 27). It should be noted however that in these cases the doctrine was neither applied nor expressly approved, and it remains unclear whether it 
proposition may be found in the Rights of Minorities case, in which the jurisdiction of the Permanent Court of International Justice was contested on the basis that the Council of the League of Nations had jurisdiction to decide on the matters at issue. The Court rejected this argument on the facts: the Council's jurisdiction concerned different petitions by individuals, not disputes between States. ${ }^{115}$ However, the Court accepted that, in principle, the possibility that the exclusive jurisdiction of another authority might limit the exercise of its jurisdiction, even when that jurisdiction is otherwise clearly established. The Court referred to Article 36(1) of its Statute, which provides for consent as a basis of the Court's jurisdiction, ${ }^{116}$ and then said as follows: 'This principle only becomes inoperative in those exceptional cases in which the dispute which States might desire to refer to the Court would fall within the exclusive jurisdiction reserved to some other authority.'117

The second situation in which a tribunal should perhaps not exercise its jurisdiction is when this would necessarily nullify the rights of a party. This will be a rare situation, but something of the sort seems to have occurred in the context of the WTO. In 2000 the United States requested a panel (which was never composed) to review certain trade related investment measures maintained by the Philippines beyond the permitted implementation period, and which had been notified under Article 5.1 of the TRIMS Agreement. ${ }^{118}$ At the time, the Philippines was waiting to hear the result of a request for an extension of the relevant implementation period from the Council for Trade in Goods, which has the authority under Article 5.3 of the TRIMS Agreement to grant extensions with respect to measures notified under Article 5.1. In addition, the WTO General Council had, by a previous Decision, mandated the Council for Trade in Goods to give 'positive consideration' to requests for an extension. 119

The difficulty here was as follows: compliance with a panel finding that the measure violated the TRIMS Agreement would have required removal of the measure, with the result that the Philippines would have lost its right,

applies in international law. In support, see Shany, above n 69 at 244 and V Lowe 'Overlapping Jurisdictions in International Tribunals' (2000) 20 Australian Yearbook of International Law 1 at 195-7.

115 Upper Silesia Rights of Minorities in [1928] PCIJ Ser A, No 15 at 23.

116 This is the precursor to Art 36(1) of the ICJ Statute.

117 Upper Silesia Rights of Minorities in, above n 113 at 23. See also Shany, above n 71 at $232-4$.

118 WTO Document Philippines-Measures Affecting Trade and Investment in the Motor Vehicle Sector-Communication from the Philippines, WT/DS195/4, 7 Nov 2002. A panel was established, though never composed: WTO Secretariat, Update of WTO Dispute Settlement Cases, WT/DS/OV/20, 26 Mar 2004

119 This decision, entitled 'TRIMs Transition Period Issues' is found in Annex II of General Council Minutes of Meeting held on 3 and 8 May 2000, WT/GC/M/55, 16 June 2000, and states that 'Members agree to direct the Council for Trade in Goods to give positive consideration to individual requests presented in accordance with Art 5.3 by developing countries for extension of transition periods for implementation of the TRIMs Agreement.' 
affirmed by the Decision of the General Council, to have the Council for Trade in Goods give 'positive consideration' to its request for an extension of the implementation period for that measure. In other words, this was not a situation in which a determination of a particular legal issue by the quasijudicial organs would prejudice a determination of the same issue by the political organs, as in the cases discussed above. Rather, it was a case where the determination of one issue by the quasi-judicial organs (the legality of the notified measure) would prejudice the determination of another issue (the extension of the implementation period for that same measure) by an organ with exclusive jurisdiction over that other issue. Indeed, in this case the situation is even more pointed, because the political organ in question not only had a right to exercise that jurisdiction, but, following the Decision of the General Council, it had a duty to do so.

Perhaps this is one of those rare situations in which the dictum in the Rights of Minorities case has a practical application.

\section{Solutions to the Problem of Institutional Balance}

If one makes the assumption that there could be a role for limiting the availability of dispute settlement in cases involving a real issue of institutional balance, as in the Philippines TRIMS dispute, the question arises as to how this might best be achieved. The following will discuss three options: (a) refusal to establish a panel by the Dispute Settlement Body, (b) a declaration by a panel that a dispute is not properly before it, and (c) suspension of proceedings pending the outcome of the relevant decision in the political organs.

(a) DSB refusal to establish a panel

As mentioned above, the primary responsibility for the management of disputes in the WTO legal system rests not with panels or the Appellate Body, but with the Dispute Settlement Body. It is consequently to this organ that one should first look to prevent inappropriate disputes from being settled in dispute settlement proceedings. This is what the Philippines sought to do in the case described above. Rather than waiting for a panel to be established, the Philippines argued within the DSB that a decision to establish a panel would be ultra vires, because it would nullify the effect of the earlier General Council decision of 8 May 2000. ${ }^{120}$ But the problem with this solution is that, as the Philippines found, under the DSU it is only by consensus that the DSB could decide not to establish a panel, with the result that the establishment of panels is effectively automatic.

120 WTO Dispute Settlement Body Minutes of Meeting held on 17 November 2000, WT/DSB/M/92, 15 Jan 2001, para 58. See also WTO Document Philippines-Measures Affecting Trade and Investment in the Motor Vehicle Sector-Communication from the Philippines, WT/DS195/4, 7 Nov 2000. 
(b) Screening by panels and the Appellate Body

There is, however, another option, which is for panels and Appellate Body themselves to manage a dispute involving a question of 'institutional balance', either by refusing to decide on the issue (as was indicated in the Rights of Minorities case) or by suspending proceedings temporarily until the political organs have reached a decision.

If panels and the Appellate Body could be equated with 'ordinary' international courts and tribunals, the ability to do this would most likely be seen as part of their inherent judicial powers. ${ }^{121}$ It is questionable, however, whether panels and the Appellate Body enjoy such powers. ${ }^{122}$ As mentioned, formally speaking panels and the Appellate Body act merely as the servants of the Dispute Settlement Body, and so it is not necessary for panels and the Appellate Body to have the full panoply of powers that might be considered essential to a normal judicial function. This is reflected in limits on the powers that they do have: panels and the Appellate Body may not make judicial orders addressed to the parties, and their reports have no binding force unless adopted by the Dispute Settlement Body. ${ }^{123}$

But even if panels and the Appellate Body lack any inherent judicial powers, this does not necessarily mean that they lack all power to regulate their proceedings, including a determination that a complaint involving a question of institutional balance should be dismissed or suspended. It only means that they must be able to base such a decision on a positive grant of authority under the Dispute Settlement Understanding. It is therefore necessary to identify whether any such authority exists.

121 In Case Concerning the Northern Cameroons (Cameroon/UK) [1963] ICJ Rep 3 (2 Dec), at 29 , the Court referred to its power to declare certain cases inadmissible on the basis that ' $[\mathrm{t}] \mathrm{he}$ Court itself, and not the parties, must be the guardian of the Court's judicial integrity'. See also Nuclear Tests (Australia/France), Judgment [1974] ICJ Rep 253 (20 Dec) at 271.

122 WTO Members have criticized comparisons between the WTO dispute settlement system and other international tribunals. See eg Special Session of the Dispute Settlement Body, Minutes of Meeting held on 10 September 2002, TN/DS/M/4, 6 November 2002, para 38 (Brazil), para 40 (Indonesia), para 42 (Malaysia), para 52 (Costa Rica), para 53 (Venezuela). See also F Weiss 'Inherent Powers of National and International Courts' in Ortino and Petersmann above n 33, who states that ' $[w] h i l e$ the $\mathrm{AB}$ searches and even seeks to expand the parameters of its power, it is too dependent upon the Members of the WTO for it to possess anything akin to inherent powers' (at 189). Weiss also questions whether the Appellate Body's decision to admit amicus curiae briefs, and its practice of 'completing the analysis' in the absence of appealed legal findings, could be considered evidence of inherent powers, but rejects this possibility on the basis that neither practice can be defended as 'necessary' to the functioning of the dispute settlement system (ibid).

${ }^{123}$ The fact that panels have the duty to determine their own jurisdiction does not give them a judicial character. The ICJ has held in the context of the United Nations that even the political organs of that organization have a duty to determine their own jurisdiction. See Certain Expenses of the United Nations (Advisory Opinion), [1962] ICJ Rep 151 (20 July) at 168, and Legal Consequences for States of the Continued Presence of South Africa in Namibia (South West Africa) Notwithstanding Security Council Resolution 276 (1970), Advisory Opinion, [1971] ICJ Rep 16 (26 Jan) at 49. 


\section{- Rejection of complaint}

(i) 'Fruitful' actions under Article 3.7 of the DSU

One possible source of authority for a panel to reject a complaint on the grounds that it would interfere with the powers of the political organs is Article 3.7 DSU. This provision states that: 'Before bringing a case, a Member shall exercise its judgement as to whether action under these procedures would be fruitful.' At best, Article 3.7 applies only with difficulty to cases involving questions of institutional balance. ${ }^{124}$ Even though it might be inadvisable to proceed to a judicial resolution of such a dispute, this does not mean that the decision would not be 'fruitful'. ${ }^{125}$ And in any case, in Mexico-Corn Syrup (Article 21.5-US), the Appellate Body declared Article 3.7 to be entirely selfjudging. It said that:

Given the 'largely self-regulating' nature of the requirement in the first sentence of Article 3.7, panels and the Appellate Body must presume, whenever a Member submits a request for establishment of a panel, that such Member does so in good faith, having duly exercised its judgement as to whether recourse to that panel would be 'fruitful'. Article 3.7 neither requires nor authorizes a panel to look behind that Member's decision and to question its exercise of judgement. Therefore, the Panel was not obliged to consider this issue on its own motion. ${ }^{126}$

This seems to go against the wording of the text, which could also be read to leave some room for objective determination by a panel. Nonetheless, the practical result is that Article 3.7 is no longer available, even to a limited degree, as a means for a panel to reject a dispute, notwithstanding the possibility that a later decision would render any findings fruitless.

(ii) 'Good faith' engaging in dispute settlement procedures under Article 3.10 of the DSU

Another possible source of power for a panel to reject a dispute is found in Article 3.10 of the DSU, which states, relevantly, as follows:

It is understood that requests for conciliation and the use of the dispute settlement procedures should not be intended or considered as contentious acts and that, if a dispute arises, all Members will engage in these procedures in good faith in an effort to resolve the dispute. ...

Article 3.10 has so far mostly been applied to the conduct of initiated dispute

\footnotetext{
124 Ehlermann, above n 77 at 305, mentions this provision in the context of cautioning selfrestraint on the part of Members in bringing institutional balance questions to dispute settlement.

${ }_{125}$ Compare the expansive reading of Art 3.7 DSU in RSJ Martha 'The Duty to Exercise Judgment on the Fruitfulness of Actions in World Trade Law' (2001) 35 Journal of World Trade 1035.

126 WTO Appellate Body Report Mexico-Corn Syrup (Art 21.5-US) above n 75 at para 74
} 
settlement proceedings before a panel or the Appellate Body. ${ }^{127}$ But can the good faith condition in Article 3.10 of the DSU also restrict the right of a WTO Member to request a panel under Article 6.1 of the DSU? This question, currently the subject of submissions in EC-Sugar, ${ }^{128}$ hinges primarily on the meaning of the terms 'if a dispute arises' and 'these procedures', and secondarily on the relationship between Articles 3.10 and 3.7 of the DSU.

It is arguable, first, that the term 'if a dispute arises' is broad enough to encompass a request for the establishment of a panel. The term 'dispute' is used in Article 1.1 of the DSU to include a request for consultations, which precedes a request for the establishment of a panel. It is therefore no great interpretive step to say that a dispute can 'arise' prior to the establishment of a panel.

The reference to 'these procedures' also seems broad enough to encompass the request to establish a panel under Article 6.1, though admittedly this is not unambiguous. In its title ('Understanding on Rules and Procedures Governing the Settlement of Disputes') and some of its provisions, ${ }^{129}$ the DSU makes an implied distinction between dispute settlement rules and dispute settlement procedures. This could be taken as giving a subordinate status to DSU procedures, which might then be understood as being limited to matters of process during dispute settlement proceedings. On the other hand, the DSU makes frequent reference to 'dispute settlement procedures' per se, which indicates that no such distinction should be made. ${ }^{130}$ Moreover, where the term 'these dispute settlement procedures' is used, it is clear that the term includes the establishment of a panel. This may be seen, for instance, in Article 21.5, which states that:

Where there is disagreement as to the existence or consistency with a covered agreement of measures taken to comply with the recommendations and rulings such dispute shall be decided through recourse to these dispute settlement procedures, including wherever possible resort to the original panel.

127 WTO Appellate Body Report US-FSC, above n 50, para 166 (noting that '[t]his pervasive principle requires both complaining and responding Members to comply with the requirements of the DSU (and related requirements in other covered agreements) in good faith); WTO Appellate Body Report Canada-Measures Affecting the Export of Civilian Aircraft, WT/DS70/AB/R, adopted 20 Aug 1999, para 190; WTO Appellate Body Report Thailand-Anti-Dumping Duties on Angles, Shapes and Sections of Iron or Non-Iron Alloy Steel and H-Beams from Poland ('Thailand-Steel'), WT/DS122/AB/R, adopted 5 Apr 2001, para 97.

128 In its First Written Submission in European Communities-Export Subsidies on Sugar, WT/DS265, 11 Mar 2004 (available at <http://www.trade-info.cec.eu.int/doclib/cfm/ doclib_type.cfm?type $=4>$ ), at paras 129 , the EC relies on Art 3.10 of the DSU as a basis for a panel to reject a claim. Australia argues in its Rebuttal Submission, 21 Apr 2004 (available at $<$ http://www.dfat.gov.au/ trade/negotiations/disputes/265_australia_rebuttal_sub.html>), at para 120, that Art 3.10 requires good faith during dispute settlement proceedings, and that it is Art 3.7 that governs the question whether a claim may be rejected. See also the parties' Oral Statements, available at the above websites.

129 Arts $1.1,1.2,2.1,2.4,3.1,3.11,3.12,23.1$, and 23.2 of the DSU.

130 Arts $3.7,3.10,10.4,12.11,21.522 .2,24.1$, and 27.3 of the DSU. 
Article 21.3 also states that ' $[\mathrm{t}]$ he Secretariat shall conduct special training courses for interested Members concerning these dispute settlement procedures and practices so as to enable Members' experts to be better informed in this regard.'

Finally, a broad interpretation of Article 3.10 is supported by USCorrosion Resistant Steel Sunset Review, in which the Appellate Body said as follows:

As long as a Member respects the principles set forth in Articles 3.7 and 3.10 of the DSU, namely, to exercise their 'judgement as to whether action under these procedures would be fruitful' and to engage in dispute settlement in good faith, then that Member is entitled to request a panel to examine measures that the Member considers nullify or impair its benefits. ${ }^{131}$

The Appellate Body made this comment in the context of rejecting the argument that a non-mandatory measure could not be the subject of dispute settlement proceedings, an issue that clearly goes to the establishment of a panel.

On balance, it seems that the principle of good faith in Article 3.10 does apply to a request to establish a panel. But even if this is wrong, it should be noted that, as a principle 'pervading' the WTO Agreements, ${ }^{132}$ the principle of good faith may in any case apply to the exercise of a WTO Member's right to request the establishment of a panel.

If so, then one must turn to the second question, whether this conclusion is affected by the 'self-regulating' right of a WTO Member to judge the fruitfulness of an action under Article 3.7 of the DSU? As mentioned, in Mexico-Corn Syrup (Article 21.5-US), the Appellate Body said that, pursuant to Article 3.7, panels and the Appellate Body must presume that a Member requesting the establishment of a panel does so in good faith. ${ }^{133}$ This statement could be taken as indicating that Article 3.7 is the exclusive provision governing the propriety of a WTO Member's decision to request the establishment of a panel under Article 6.1. However, while it clearly leaves no room for analysis of the motives of a complainant WTO Member under Article 3.7, this statement does not necessarily exclude the possibility that panels and the Appellate Body are entitled to investigate these motives under Article 3.10. Nor does it mean that the apparently irrebuttable presumption of good faith under Article 3.7 necessarily applies to Article 3.10.

For these reasons, it will be assumed that the principle of good faith in Article 3.10 does apply to requests to establish a panel, although clearly the

131 WTO Appellate Body Report United States-Sunset Review of Anti-Dumping Duties on Corrosion Resistant Carbon Steel Flat Products from Japan ('US-Corrosion Resistant Steel Sunset Review'), WT/DS244/AB/R, adopted 9 Jan 2004.

132 WTO Appellate Body Report US-FSC, above n 50, para 166; WTO Appellate Body Report United States-Transitional Safeguard Measure on Combed Cotton Yarn from Pakistan ('US-Cotton Yarn'), WT/DS192/AB/R, adopted 5 Nov 2001, para 81.

133 Above n 126. 
legal situation is still ambiguous. The following will therefore consider what the principle of good faith might entail, in this specific circumstance.

(iii) Good faith

In international law, the principle of good faith has an operative effect, but it is not itself a source of rights or obligations. As was said by the ICJ:

The principle of good faith is, as the Court has observed, 'one of the basic principles governing the creation and performance of legal obligations' (Nuclear Tests, [. . .]); it is not in itself a source of obligation where none would otherwise exist. ${ }^{134}$

The principle of good faith has a number of aspects, depending on the circumstances. ${ }^{135}$ The present context concerns the exercise of a WTO Member's right to request the establishment of a panel. Here, the following definition of good faith is pertinent:

The essence of the doctrine is that although a State may have a strict right to act in a particular way, it must not exercise this right in such a manner as to constitute an abuse of it; it must exercise its rights in good faith and with a sense of responsibility; it must have bona fide reasons for what it does, and not act arbitrarily or capriciously. ${ }^{136}$

The principle of good faith has been related to the doctrine of the abuse of rights, which prohibits a State from 'exercising a right either in a way which impedes the enjoyment by other States of their own rights or for an end different from that for which the right was created, to the injury of another State'. ${ }^{137}$ This connection has also been made by the Appellate Body, when it described the Chapeau of Article XX as follows:

The chapeau of Article XX is, in fact, but one expression of the principle of good faith. This principle, at once a general principle of law and a general prin-

134 Border and Transborder Armed Actions (Nicaragua/Honduras), Jurisdiction and Admissibility, Judgment [1988] ICJ Rep 69 (Dec 20) at para 94. In Case Concerning the Land and Maritime Boundary Between Cameroon and Nigeria (Cameroon/Nigeria), Preliminary Objections [1998] ICJ Rep 275 (11 June), the ICJ held that the principle of good faith did not require a State to inform another State subject to compulsory jurisdiction of the Court that it was intending to accept compulsory jurisdiction, and shortly thereafter to commence proceedings against that State.

135 Regarding the obligation to perform obligations in good faith (reflected in Art 26 of the Vienna Convention on the Law of Treaties), see II Lukashuk 'New Thinking by Soviet Scholars: The Principle Pacta Sunt Servanda and the Nature of Obligation under International Law' (1989) 83 AJIL 513 at 514, who notes that '[i]n jurisprudence the term "obligation" is not equivalent to the term "duty", since the former includes not only duties, but also relevant rights. Rights, too, should be exercised in good faith, ie, in conformity with the purposes and principles of international law and without prejudice to the legitimate interests and rights of other subjects of that law.'

${ }^{136}$ G Fitzmaurice The Law and Procedure of the International Court of Justice (Cambridge Grotius 1986) vol 1 at $12-13$

137 A Kiss 'Abuse of Rights' in Encyclopaedia of Public International Law (Amsterdam NorthHolland 1984) at 4. For a fuller discussion of the doctrine, see V Paul 'The Abuse of Rights and Bona Fides in International Law' (1977) 28 Österreichische Zeitschrift für Öffentliches Recht und Völkerrecht 107. 
ciple of international law, controls the exercise of rights by states. One application of this general principle, the application widely known as the doctrine of abus de droit, prohibits the abusive exercise of a state's rights and enjoins that whenever the assertion of a right 'impinges on the field covered by [a] treaty obligation, it must be exercised bona fide, that is to say, reasonably'. ${ }^{138}$

There are, no doubt, many situations in which the principle of good faith may operate to restrain the exercise of a WTO Member's right to request the establishment of a panel under Article 6.1 of the DSU. One such situation might be where a request for a panel is made for reasons other than the resolution of a dispute. For example, it might be argued that a WTO Member is not acting in good faith if it requests a panel for the purpose of nullifying the substantive rights of another WTO Member. But it is harder to argue that a WTO Member would not be acting in good faith if its request merely has the effect of nullifying such rights (as might have occurred in the Philippines-TRIMS case mentioned above). Consequently, even in cases involving questions of 'institutional balance', it will be rare that the principle of good faith will give a panel any reason to reject a dispute.

\section{- Suspension of proceedings}

If the DSU does not unambiguously allow a panel or the Appellate Body to decline to hear a dispute in a case involving institutional balance issues, does it authorize these organs to suspend proceedings, pending resolution of the matter in the competent political organ? Such a course of action was followed in the MOX Plant Arbitration (UK/Ireland), which was heard by an arbitral tribunal appointed pursuant to Annex VII of the UN Convention on the Law of the Sea. In these proceedings, the arbitrators ordered the suspension of proceedings for five months, so that various issues material to the question of jurisdiction ${ }^{139}$ could be decided in a more appropriate forum (the European Court of Justice). ${ }^{140}$ The Order was justified as follows:

bearing in mind considerations of mutual respect and comity which should prevail between judicial institutions both of which may be called upon to determine rights and obligations as between two States, the Tribunal considers that it

138 WTO Appellate Body Report US-Shrimp, above n 40, para 158. The Appellate Body quoted B Cheng General Principles of Law as Applied by International Courts and Tribunals (Stevens and Sons 1953).

139 These issues concerned the standing of the parties before the Tribunal, the division of competences between the European Community and its Members States with respect to UNCLOS, and the exclusive jurisdiction of the European Court of Justice. Another problem was 'the extent to which provisions and instruments invoked by the Parties may properly be relied upon before this Tribunal'. See MOX Plant Arbitration (Ireland/UK), Order No 3, Suspension of Proceedings on Jurisdiction and Merits and Request for Further Provisional Measures, 24 June 2003, Arbitral Tribunal constituted under Art 287 and Annex 1, Art 1 of UNCLOS, available at $<$ http://www.pca/cap.org > at para 20.

${ }^{140}$ This exact situation was foreshadowed in Lowe, above n 114 at 199. 
would be inappropriate for it to proceed further with hearing the Parties on the merits of the dispute in the absence of a resolution of the problems referred to. Moreover, a procedure that might result in two conflicting decisions on the same issue would not be helpful to the resolution of the dispute between the Parties. ${ }^{141}$

The Tribunal made its Order on the basis of a provision in its Rules of Procedure which stated as follows:

Subject to these Rules, the Arbitral Tribunal may conduct the proceedings in such manner as it considers appropriate, provided that the Parties are treated with equality, and that at any stage of the proceedings each Party is given a full opportunity to be heard and to present its case. ${ }^{142}$

Below, the question will be discussed whether a panel or the Appellate Body can resort to their Working Procedures in similar circumstances. Before coming to this, however, it is necessary to discuss an express provision that exists in the DSU entitling panels, though not the Appellate Body, to suspend proceedings at the request of the complainant.

\section{- Suspension of proceedings under Article 12.12 DSU}

Article 12.12 DSU grants panels the express power to suspend proceedings at the request of the complaining party. It states, relevantly, as follows:

The panel may suspend its work at any time at the request of the complaining party for a period not to exceed 12 months ... If the work of the panel has been suspended for more than 12 months, the authority for establishment of the panel shall lapse.

Whether Article 12.12 would very much assist a panel faced with a dispute involving a question of institutional balance may be doubted, as this provision entitles a panel to act only at the request of the complaining party. ${ }^{143}$ There is nothing that would authorize a panel, of its own motion, or on request by a defendant, to suspend proceedings. In the MOX Plant Arbitration, the tribunal acted of its own motion and the parties did not object

141 MOX Plant Arbitration (Ireland/UK), Order No 3, above n 139, para 28. A further suspension was ordered in MOX Plant Arbitration (Ireland/UK), Order No 4, Further Suspension of Proceedings on Jurisdiction and Merits, 14 Nov 2003, Arbitral Tribunal constituted under Art 287 and Annex 1, Art 1 of UNCLOS, available at <http://www.pca-cap.org>.

142 MOX Plant Arbitration (Ireland/UK), Rules of Procedure, Arbitral Tribunal constituted under Art 287 and Annex 1, Art 1 of UNCLOS, available at <http://www.pca-cap.org>.

143 The panel also retains a discretion not to suspend proceedings even on request of the complainant. In this context, it is relevant to note the joint proposal by Chile and the United States, which would amend Art 12.12 to entitle the parties to a dispute to require a panel to suspend proceedings. See WTO Document TN/DS/W/52, 14 Mar 2003, above n 31 at para (d). Compare Rule 30(1) of the Appellate Body's Working Procedures, below n 146 which states that '[a]t any time during an appeal, the appellant may withdraw its appeal by notifying the Appellate Body, which shall forthwith notify the DSB.' 
to the suspension of proceedings. ${ }^{144}$ This would not be possible under Article 12.12 .

- Powers of Panels and the Appellate Body under their Working Procedures

It seems then, that the DSU does not expressly allow panels or the Appellate Body either to reject disputes involving questions of institutional balance, or to suspend proceedings temporarily, of their own motion, in such circumstances. But might panels and the Appellate Body have such powers under their Working Procedures?

Panels may adopt Working Procedures under Article 12.1 DSU, which states that: 'Panels shall follow the Working Procedures in Appendix 3 unless the panel decides otherwise after consulting the parties to the dispute.' While a panel must consult with the parties before adopting working procedures, it is under no obligation to obtain their agreement to such procedures, even if this may be desirable. ${ }^{145}$

For the Appellate Body the relevant provision is Article 17.9, which states that: 'Working procedures shall be drawn up by the Appellate Body in consultation with the Chairman of the DSB and the Director-General, and communicated to the Members for their information.' The Appellate Body has drawn up detailed standing Working Procedures under this provision. ${ }^{146}$ It is important to mention Rule 16(1) of these Procedures, which states that:

In the interests of fairness and orderly procedure in the conduct of an appeal, where a procedural question arises that is not covered by these Rules, a division may adopt an appropriate procedure for the purposes of that appeal only, provided that it is not inconsistent with the DSU, the other covered agreements and these Rules....

Neither the panels' Working Procedures in Appendix 3 nor the Appellate Body's Working Procedures drawn up under Article 17.9 of the DSU say anything about the possibility of rejecting a complaint or suspending proceedings, even if this would be 'helpful to the resolution of the dispute between the Parties' (to adopt the words of the tribunal in the MOX Plant

144 MOX Plant Arbitration (Ireland/UK), Transcript of Proceedings, Day Eight, 21 June 2003, Arbitral Tribunal constituted under Art 287 and Annex 1, Art 1 of UNCLOS, available at <http://www.pca-cap.org> at paras 37, 38, and 90. It is perhaps relevant that both parties are bound in this regard by a duty of cooperation under Art 10 of the EC Treaty.

145 See WTO Panel Report United States-Imposition of Countervailing Duties on Certain HotRolled Lead and Bismuth Carbon Steel Products Originating in the United Kingdom ('US-Lead and Bismuth II'), WT/DS138/R, adopted as upheld by the Appellate Body Report 7 June 2000, at para 6.2 .

146 The current version is WTO Document Working Procedures for Appellate Review, WT/AB/WP/7, 1 May 2003. The Appellate Body circulated proposed amendments for consultation in WTO Document Proposed Amendments to the Working Procedures for Appellate Review-Communication from the Appellate Body, WT/AB/WP/8, 8 Apr 2004. 
Arbitration). This raises the question whether such powers can be inferred from the nature of Working Procedures in general.

The Appellate Body has adopted a generous interpretation of its own powers and the powers of a panel to adopt Working Procedures. It said in EC-Hormones that 'the DSU, and in particular its Appendix 3, leave panels a margin of discretion to deal, always in accordance with due process, with specific situations that may arise in a particular case and that are not explicitly regulated'. ${ }^{147}$ This is subject to the proviso that a panel acting under Article 12.1 DSU must comply with the substantive provisions of the DSU. ${ }^{148}$ On its own power to adopt Working Procedures, the Appellate Body has said, similarly, that 'the Appellate Body has broad authority to adopt procedural rules which do not conflict with any rules and procedures in the DSU or the covered agreements'. ${ }^{149}$

Does this mean that a panel or the Appellate Body may use their Working Procedures to refuse to hear a dispute? This is unlikely, as it is only for the purpose of hearing a 'particular case' that Working Procedures are to be adopted. It would be difficult to interpret the authority to adopt Working Procedures as covering a decision to reject a dispute entirely, even if this is for otherwise good reasons. On the other hand, panels and the Appellate Body may yet have the power temporarily to suspend proceedings. Such an action is not a final resolution of the dispute, nor does it mean that the panel or Appellate Body do not remain seized of the matter. Here it seems much easier to justify an analogy with the power exercised by the tribunal in the MOX Plant Arbitration, which, as noted, took effect pursuant to a rule governing the conduct of proceedings.

There is, however, an additional restriction on panels and the Appellate Body, which did not apply to the tribunal in that arbitration, namely, that panels and the Appellate Body are under an obligation to comply with the time limits set out in Articles 12.8 and 12.9 (for panels) and Article 17.5 DSU (for the Appellate Body). ${ }^{150}$ Even if panels and the Appellate Body have the

147 WTO Appellate Body Report EC-Hormones, above n 39, para 152 n 138.

148 WTO Appellate Body Report India-Patent Protection for Pharmaceutical and Agricultural Chemical Products ('India-Patents (US)'), WT/DS50/AB/R, adopted 16 Jan 1998, at para 92.

149 WTO Appellate Body Report United States-Imposition of Countervailing Duties on Certain Hot-Rolled Lead and Bismuth Carbon Steel Products Originating in the United Kingdom ('US-Lead and Bismuth II'), WT/DS138/ABR, adopted 7 June 2000, at para 39. This proviso is reflected in Rule 16(1) of the Appellate Body's Working Procedures.

150 Art 12.8 DSU states that 'the period in which the panel shall conduct its examination ... shall, as a general rule, not exceed six months' and Art 12.9 provides that in no case should the period from the establishment of the panel to the circulation of the report to the Members exceed nine months'. In similar fashion, Art 17.5 DSU recommends that the Appellate Body circulate its report within 60 days, and requires it to do so within 90 days. There is also a week-by-week timetable established for panel proceedings in Appendix 3 of the DSU, although this may be altered by the panel after consulting with the parties to the dispute. In addition to these provisions, it is necessary to mention Art $20 \mathrm{DSU}$, which implies that the parties may agree to extend the time period for panel and Appellate Body proceedings, despite the obligations imposed on panels and the Appellate Body to issue their reports within nine and three months respectively. Art 20 also 
power to suspend proceedings under their Working Procedures, any suspension that would take proceedings beyond the deadlines in these provisions would appear to be prohibited. ${ }^{151}$ Given the length of time that it would take to reach any alternative decision, this may, in practice, turn out to limit much of the utility of this solution.

\section{CONCLUSIONS}

Based on this review, the following conclusions may be stated. It is genuinely problematic that the political organs are unable to act, except by consensus, while the dispute settlement system is constructed in such a way that there is virtually no means of preventing potentially explosive cases from reaching their final end. On the other hand, many of the fears about 'judicial activism' in the WTO appear to be misplaced, or at least rhetorically overblown. Most of the discontent with the existing practice of panels and the Appellate Body may be reduced to disagreement with the results of particular cases, and in particular with the underlying law. This is quite different from the charge that the quasi-judicial organs are 'legislating' instead of applying the law as they see it.

Still, there are some rare cases in which a decision by a panel or the Appellate Body might do harm to the rights and obligations of WTO Members, and to the allocation of powers to the political organs under the WTO Agreement. This article has examined two types of case in which this could occur - where the law is genuinely indeterminate, and where a decision by the quasi-judicial organs interferes with the powers of the political organs - and has proposed solutions based not on strengthening political control over the dispute settlement process, but rather on strengthening the powers of panels and the Appellate Body to manage such cases properly.

This leads to the following practical suggestions. First panels and the Appellate Body both can and should declare a non liquet in cases when the law is indeterminate. Secondly, panels and the Appellate Body should be unambiguously granted the power to reject cases where this would interfere with the powers of the political organs (as well as in other cases of 'inadmissibility'), in line with the dictum in the Rights of Minorities case. Thirdly,

confusingly describes the nine month deadline in Art 12.9 as 'a general rule', to which the extra time allowed pursuant to Arts 12.9 and 17.5 is to be added.

151 In WTO Appellate Body Report US-Lead and Bismuth II, above n 149, at para 8, the Appellate Body took a decision under Rule 16(1) of the Working Procedures that contradicted the time limit in Art 17.5 of the DSU. The parties agreed with the Appellate Body to extend the 90day period for circulation of the report by two weeks. However, this was necessary to accommodate the passing away of one of the Members of the Appellate Body Division hearing the appeal, and it would be difficult to extract much of value from this occurrence. The 90-day period was also exceeded in WTO Appellate Body Report EC-Hormones, above n 39, WTO Appellate Body Report EC-Asbestos, above n 1, and WTO Appellate Body Report Thailand-Steel, above n 127. 
panels and the Appellate Body should be granted the power to suspend cases temporarily in order to allow for a decision to be reached in a political forum (or another judicial forum), as was done in the MOX Plant Arbitration.

The first of these proposals may seem radical, but, exercised with appropriate caution, it would arguably better serve the integrity of the dispute settlement system than a controversial decision with little legitimacy. The second and third would do no more than bring panels and the Appellate Body into line with other international tribunals. These solutions are perhaps not optimal, but for so long as WTO Members continue their practice of voting by consensus on every issue, they may provide a useful safety valve in a system in which the allocation of powers between the political quasi-judicial organs has become seriously unbalanced. 